\begin{tabular}{l|l}
$\mathbf{m} \boldsymbol{m}$ & $\begin{array}{l}\text { south } \\
\text { asia }\end{array}$
\end{tabular}

samaj multidisciplinary

uilu academic

III academic
South Asia Multidisciplinary Academic Journal

$12 \mid 2015$

On Names in South Asia: Iteration, (Im)propriety and Dissimulation

\title{
Naming Beyond Pointing: Singularity, Relatedness and the Foreshadowing of Death
}

\section{Veena Das}

\section{(2) OpenEdition}

\section{Journals}

Electronic version

URL: http://journals.openedition.org/samaj/4005

DOI: $10.4000 /$ samaj.4005

ISSN: 1960-6060

Publisher

Association pour la recherche sur l'Asie du Sud (ARAS)

Electronic reference

Veena Das, « Naming Beyond Pointing: Singularity, Relatedness and the Foreshadowing of Death », South Asia Multidisciplinary Academic Journal [Online], 12 | 2015, Online since 15 October 2015, connection on 20 April 2019. URL : http://journals.openedition.org/samaj/4005 ; DOI : 10.4000/ samaj.4005

This text was automatically generated on 20 April 2019

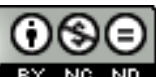

This work is licensed under a Creative Commons Attribution-NonCommercial-NoDerivatives 4.0 International License. 


\title{
Naming Beyond Pointing: Singularity, Relatedness and the Foreshadowing of Death
}

\author{
Veena Das
}

1 While proper names are seen as a test case for theories of reference in much of analytical philosophy, anthropologists have been much more interested in showing if a theory of names might be generated from the actual practices around names and naming practices in different societies. ${ }^{1}$ In a discussion on proper names that has achieved canonical status in anthropology, Lévi-Strauss singled out two important aspects of naming-first, that one's relation to one's name lies between the two poles of immutability and stability on the one side and changeability and volatility, on the other; second, that there is a foreshadowing of death in the investment of a ghostly being in a name (LéviStrauss 1966). To these two aspects one might add a third, which grows from LéviStrauss's contention that proper names always remain at the margins of classification. Once a name is seen as a proper name, he says, it is assigned to a level beyond which it ceases to be a matter of classification, which implies that while sometimes names can be proper names that indicate identity such as caste names, or family names that are stable, at other times, they might be condensations of events such as who one is or has become because of events as blessed as the birth of a child or as devastating as the death of a relationship. This possibility of the name as encapsulating events draws attention to the fact that over the life course a name signifies not only continuity of who one is in terms of a personal identity, but also unpredictability in one's relation to others. New names might be added to existing ones as a complement to the singularity of being or in opposition to it. Said otherwise, names, like persons, course through lives so names, like bodies, often carry the traces of the changes that have occurred in the life of a person.

2 Lévi-Strauss based much of his discussion on names on the ethnography of Penan, a group of forest nomads living in the interior of north-western Borneo studied by Rodney Needham (1954) who noted that 'In the general extreme simplicity of Penan culture the types of names and the usages connected with them stand out in surprising complexity' 
(Needham 1954: 416). Penan names are distinguished between personal names, tekonyms (e.g., father of so and so) and necronyms in which a kinship relation to a deceased relative comes to replace the proper name. Needham's account showed that individuals must necessarily move between different names over a lifetime. A child might start with a proper name till one of his ascendants dies at which time he sheds the proper name and takes on the necronym (e.g. father dead). If a sibling dies the child takes the name-sibling dead-since the necronym is not a proper name but the indication of the relationship to a deceased relative. When a child bearing a necronym of a sibling is blessed with a new sibling, she reverts back to her initial proper name. As a child grows into adulthood he or she might move to a tekonym-so-and-so's father, so-and-so's mother. Thus a person might pass through six or seven names before he or she marries and has children.

Does this discussion of Penan names provide a more general framework for understanding what is at stake for anthropologists in understanding the volatility and changeability of names? While Lévi-Strauss was interested in the structural implications of these naming practices, their movements of ascent and descent, I am intrigued by another aspect-that of proclaiming or withholding a particular name from among the multiplicity of personal names that are usually given to an individual in India. I argue that attention to these aspects of naming offers a key to understanding the lethal potential that inheres in all intimate relations. The double character of names-that they can be signs of intimacy that restricts their circulation and also signs of the aspiration to be projected outward into publicity-seems to require not one definitive description but a series of descriptions through which the significance of names and naming practices might be disclosed. As I will argue, names appear sometimes to be located in secure conventions but at other times they are thrown into the whirl of events as the subject faces the risk of losing hold over the security of his or her name.

In order to build my argument I take two kinds of insights-first from literary texts, especially the Rāmāyana (and its vernacular versions) and the Mahābhārata-and second from my long tern ethnographic engagement with low-income residents of Delhi (see Das 2015). That anthropologists should find an intimacy with literature in their thinking is not a surprise. Marc Augé (2011) speaks of the silent conversation between anthropologists and works of fiction. Other anthropologists, especially Michael Jackson (2013) and Vincent Crapanzano (2003), have established the affinity between literature and anthropology as integral to the anthropological way of knowing. In my own work on catastrophic violence I felt that we turn to the poets to give us words when we ourselves stumble in the face of violence and suffering (Das 2007). In much of this writing, the conversation between literature and anthropology is seen as taking place in the space between fieldwork and writing, helping in the modes of interpretation, providing words when our own vocabularies fail or regarding the literary as providing a model for constructing the anthropological text. In this paper, though, I am interested in two different levels at which this conversation becomes possible-one, when we find literary and philosophical expressions in the speech of our respondents in the field and second, as we look at writers as fellow travelers whose aesthetic rendering of what is happening provides insights on how to become awakened to the world that we as anthropologists might try to disclose in our own writing. In the case of the epics in India, which are part of living traditions, my respondents often evoked such stories as a way to speak about events and about their relationships. Irawati Karve (2008) argued for a similar sensitivity in her pioneering analysis of the characters in the Mahābhārata. Elsewhere I have 
developed a more sustained argument on the modalities through which we might think of literature as enabling us to focus or to hold still certain moments that would otherwise pass us by; one might compare this with still life paintings or a close up as a cinematic moment in which the dispersed emotions might be gathered and condensed (Das 2015). I hope that the methodological risks that I take by juxtaposing significant moments in a text with insights from ethnographic vignettes will help me reveal how concepts that we use in anthropology might well be seen as growing from everyday life rather than being 'applied' to everyday life and that literature might help us to theorize in a different modality than that of say, axiomatic reasoning.

\section{How can I bear my name? The lament of Bharata}

5 The temporal unfolding of different contexts through which one's life moves bring to the fore new ways of experiencing one's own name. Think in the literary register of the wellknown lament of Romeo-'My name, dear saint, is hateful to myself, Because it is an enemy to thee.' In this section I take up the question: when is it that a name that was proudly borne, becomes difficult to bear either because one begins to see oneself through the eyes of another who brings to the surface of consciousness an aspect of the self that was previously seen as unremarkable (in the case of Romeo, the long history of clan enmity); or because what has been proclaimed on behalf of one's name is experienced as out of harmony with one's own sense of the self. This existential relation to the namethat it is both mine and yet not under my control, for I might become obliged to bear the consequences of another's actions taken on my behalf, brings out the vulnerability to the other that my name exposes me to. I argue that the events I will describe here show how my own name can make me vulnerable to the world not seen as an objective overarching reality out there but as 'my world,' made through modes of appropriation and unfolding of events in which I might become implicated. My first example of this kind of vulnerability and how it changes one's experience of one's name is taken from the wellknown episode in the Ayodhya Kānda in which the hero of the epic, Rāma, has been exiled to the forest through what the epic sees as the machinations of Kaikeyī, the youngest wife of his father, who wants the kingdom for her own son, Bharata.

In order to place this episode in the larger narrative context let me briefly recapitulate the main story of the Rāmāyana, the original text in Sanskrit on which later versions in India and South East Asia are based. There is a vast literature on the many versions of the Rāmāyana story in Sanskrit and in vernacular languages as well as the textual and performance traditions based on this story in different regions in India (see Lutgendorf 1991; Richman 1991). The simplest rendering of the main story goes as follows:

7 After a long period of childlessness, the king of Ayodhyā, Daśratha, performed a royal fire-sacrifice for the realization of his wish for the birth of a son. Through divine intervention, he was given a fruit that was shared between his three wives who then gave birth to four sons, Rāma, Lakșmaṇa, Bharata and Shatrughṇa. As part of their initiation into adulthood, Rāma and Lakșmana were sent to the forest to get rid of the demons that were troubling the renouncers and disrupting their sacrificial fires. In the course of their sojourns, Rāma won the hand of the beautiful princess Sìtā, daughter of the learned King Janaka of Videha. Rāma was, however, again exiled to the forest for 14 years through the plotting of the youngest queen, Kaikeyi as we saw, who wanted the kingdom for her son, 
Bharata. His brother, Lakṣmaṇa and his wife, Sìtā, accompanied Rāma in his exile to the forest. King Daśratha died of grief at this unbearable turn of events. Bharata was inconsolable when he learnt what his mother had done, and that too under the presumption that he would acquiesce in her plan. Refusing to accept the status of king, he ruled Ayodhyā for fourteen years as the 'servant' of Rāma rather than its ruler. Another grievous event happened during the second exile. Rāvana, the demon king of Lankā, abducted Sitā. Following this event, Rāma gathered an army of monkeys and bears to search for her. The allies attacked Lankā, killed Rāvanana, and rescued Sitā. In order to prove her chastity, Sìtā had to undergo a fire ordeal, but was vindicated by the gods and restored to her husband. After the couple's triumphant return to Ayodhyā, Rāma's righteous rule (Rāma-räjya) was inaugurated but soon after (depending on the version of the text one is reading), Sitā was exiled again because of rumors about her chastity. Given refuge in the āśrama of the sage Vālmiki, the author of the original Rāmāyana, she gave birth to two sons. Though Rāma was ready to take her back after her second ordeal by fire, she refused to return to Ayodhyā, choosing to be swallowed by her mother, the earth from which she had been born, rather than accepting the ignominy of living with rumors about her chastity. In the Rāmacaritamānasa, the vernacular rendering of this story that we shall be considering, the episode of the second exile is expunged on the ground that it was a shadow Sìtā who was abducted by Rāvaṇa-an interesting narrative device for making a shift in the story more consonant with the feeling that Sitā's chastity was never in doubt. ${ }^{2}$

8 I have analyzed the narrative structure of the text, including the various coda elsewhere (see Das 1982). Here I will focus on some iconic moments in the text that portray Bharata's lament on hearing of his mother's ignoble actions and the verbal devices used (especially that of swearing), by which he is exonerated from any hint of complicity with Kaikeyī through the words of Rāma and his mother Kauśalyā. As we shall see, a swirl of imaginaries around names emerges in these verses, providing a rich provocation to think of the relation between name and vulnerability.

9 Let us, then, go in our imagination to the palace in Ayodhya where Bharata and Shatrughṇa the two younger princes have been summoned to return from their sojourn in Bharata's maternal uncle's kingdom. They know nothing yet of the misfortunes that have befallen Ayodhyā-the exile of Rāma, Lakșmaṇa and Sitā to the forest through the devious acts (as the text sees it) of Kaikeyī and the death of their father, Daśaratha. Kaikeyi had assumed that Bharata would be pleased at the ascension to the position of king for in her own eyes she had acted for his benefit-yet to her dismay Bharata fell into a rage on hearing what she had done, accusing her of the worst possible sin committed not only against Daśaratha and Rāma but against Bharata himself.

10 Here is how Kaikeyi announces what she has been able to do in Bharata's absence when he makes the usual polite inquiries about everyone's well-being:

tāt bāat main sakal samvārī bhai mantharā sahāy bechārī

kachuk kāja vidhi bìca bigādeu bhūpati surpati pur pagu dhāreu (Ayodhyā Kāṇda, Verse 149/1)

11 Tāt (lit. grandfather or little father, an affectionate way of addressing a child), I have taken care of all with the help of Mantharā-though fate spoiled some things-the lord of the earth (i.e. the king) left for the abode of gods.

Kaikeyī reveals the full extent of the story in which she had been counselled by Mantharā (her maid) to ask the king to honor an earlier vow that he would fulfill any two wishes she 
asked for. After Kaikeyī had ensured that Daśratha took an oath on the name of Rāma that he would not renege on his promise, she demanded that Rāma be exiled to the forest for fourteen years and Bharata be crowned as king. Bharata is stunned at this treachery that has led to the exile of his elder brother and the infamy that awaits him now of conspiring against his own brother for the love of a kingdom. He lashes out at Kaikeyī, calling her a sinful woman and asking that if she had such hatred toward him, why had she not killed him at the moment of his birth so that he would not have had to carry the ignominy of coming to be known as Rāma's enemy.

Among the many passages on Bharata's lament, let us take the following two:

Hansbansu Daśaratha janaku Rāma Lakhan se Bhāi

Janani tu jananī bhai vidhi san kahu nā basāi (Ayodhyā Kāṇda, Verse 161)

I was born in the lineage of the sun, Daśaratha is my father,

brothers as (great as) Rāma and Lakșmana,

Yet, you (lowly) woman, became my mother-who can argue with fate?

And now take the following verse.

Kaikeyī sujhan jogaj jag joi, catur viraci dīna mohi sokandī

Daśaratha tanay Rāma laghu bhaī,

dìna mohì vidhi baḍi baḍai (Ayodhyā Kānḍa, Verse 180/1)

Freely translated it reads as follows:

That Kaikeyi who has become defamed in the world

And clever fate has assigned me to that very person

I am the son of Daśaratha

and the younger brother of Rāma

But fate has done me such a great favor (by making Kaikeyī my mother).

There are other powerful verses in which Bharata laments as to why Kaikeyī was born in the world, if she had to be born, why was she not infertile (bānjh) and if she were to have a son, why was that son Bharata?

In an earlier paper on these episodes (Das 1982), I argued that the violent rejection of the mother here is part of the story of fathers and sons-the mother is the conduit through which sons come to be attached to their father's lineages, but once a son's place is fully secured in the patrilineage, the mother is expected to efface herself. Bharata's rage against his mother is not only on grounds of abstract moral principles (for she had held Daśaratha to a moral contract they had made and hence had, strictly speaking, committed no offence), but rather because she had broken the unspoken understanding of how mothers must efface themselves from the unbroken connections between fathers and sons. Bharata's rage, however, is not related only to the public blemish but also to the sense of disgust he feels at having been born of Kaikeyī, and of being expelled from the fraternity of brothers. I find the play between the proper name Bharata and the tekonyms -son of Daśaratha, younger brother of Rāma-quite fascinating. While the patronymics are embraced as badges of honor-the name Kaikeyī putra-the son of Kaikeyī becomes a source of shame. Bharata shrinks from this appellation as from something that bites him from within. This is particularly remarkable in the text since in the previous chapter, when Bharata was bidding farewell to his maternal uncle, King Kaikeya, he had embraced the blessings and the tekonym-son of Kaikeyi-the very connection he was to reject violently in the next section. The names thus become condensations of swirling affects of regret, lament, blame, desire and aspiration. The issue is not that of reference-how does a proper name refer, to isolate who the bearer is-but rather of reaching into the open 
texture of the name through which a range of affects can be condensed and presented all at once without need of further description.

17 A second aspect of the name that the text reveals is that one's name might also make one vulnerable to another not through hate but through love. The verse I want to take here is that in which Kauśalyā, Rāma's mother, who comes forward herself to exonerate Bharata from any suspicion of complicity with what has transpired. Bharata had gone to the forest to beg Rāma to return and take up the reigns of the kingdom and to offer to take Rāma's place in exile. There follows an initial misunderstanding primarily on the part of Lakșmana and some others who thought that Bharata was coming to wage war against a defenseless Rāma. Their fears were assuaged by Rāma who swore on the name of his revered, lamented father and on the name of Lakșmana that he could vouch that Bharata was incapable of bearing any enmity to him. The same suspicion arose once again-this time in the mind of Janaka, the king of Mithilā and the father of Sìtā and his wife Sunayanā-and was again calmed by Kauśalyā's swearing on the name of Rāma that Bharata had not been part of the conspiracy to exile Rāma. Instead, she attributed this terrible turn of events to the machinations of fate. Kauśalyā's words are particularly interesting here for she says, 'Rāma śapath main kīnhī nā kāu, so kari kahūn sakhī sati bhau' ( Ayodhya ā Kānda, Verse 282/1) -I have never sworn by Rāma but now doing that, oh friend, I speak with truthfulness (of Bharata's devotion to Rāma).

Why does this cultural notion-that someone who stands in an intimate relation to another, might use the name of this intimate other to establish the truth, and elicit the faith of the listener, by taking an oath on his or her name-make one vulnerable to the other and even to the world? First of all, I suggest that what such an act of swearing does is to make the loved other into a ransom to be redeemed by the truthfulness of the utterance-for the one whose name serves as the means for asserting the truth, it is as if in being so implicated through the act of swearing, one has been forced to recognize that one is always vulnerable to the words and gestures of another. Kauśalyā proclaims that she has never sworn by the name of Rāma-she makes an exception for the sake of Bharata just as Rāma had calmed Lakṣmana earlier by swearing on his name. But can she be certain that Bharata will not betray her?

19 What is the risk one takes in swearing on the name of a loved one? I suggest that the risk is that of putting a beloved person in danger. For if my words turn out not to be true, some harm would result to him or her-one has gambled on how much trust or confidence one might place in one's ability to read the other, or even oneself. Take Kauśalyā's utterance-she says she never swears on the name of Rāma-in other words, however confident she might be of her own intentions, she would never put Rāma at any risk of misfortune. But now in proclaiming that Bharata could never have been swayed by any love for the kingdom to betray Rāma, she has betted on Rāma, trusting that what she knows of Bharata is true. But suppose Bharata turned out to be like other brothers who deceive each other, then not only would she be betrayed but she might also have betrayed Rāma by swearing on his name. Ideally the text seems to suggest that one should never take someone one loves as the instrument for winning the faith of others. In a world in which we could be certain of our loves, and of our faith in the others with whom we live, we would never put another at risk through our actions-but the text seems to suggest that swearing by another is a mode of speech through which our words may, irrespective of our intentions, jeopardize the good fortune or even the lives of those we love. 

found in the exchange between Kaikeyī and Daśaratha when she asks that the two boons the king had promised now be redeemed. Mantharā had advised the queen that in order to bind the king completely to his words she must get him to swear by Rāma so that he would be bound to grant her whatever she asked for. In their exchange the king says that he loves Kaikeyĩ so much that he is not unwilling to swear by Rāma and yet when he hears that she wants Rāma to be exiled, he realizes that he has ransomed his son to the wrong person. This imagination of the character of intimacy and uncertainty draws on the name as that aspect of the self that is in the hands of those we love and in whose hands we may find redemption or destruction. Of course when I promise to do something, swearing by my most beloved intimate other, I create trust in my words. This is why swearing must always be in the name of someone one loves-it would make no sense to swear by the name of a stranger-but it also points to our ability to put those we love at risk by our own actions thus revealing the dark potential of names.

The closeness of Tulsidas's language to everyday life among the families I have followed in my work comes out in stark relief in my fieldwork notes. In the exchange between Kaikeyi and Bharata, the commentary of the poet draws on many homely analogies-for instance, that her words were like salt rubbed on a burn wound (jale par namak lagānā) or referring to the anger that Shatrughṇa felt at the sight of Mantharā using the analogy of fire having received an a huti-the offering that causes it to burn more vigorously. These modes of speaking are, indeed, prevalent in the everyday speech of the communities I have studied. Equally prevalent is the practice of swearing or taking an oath on the name of an intimate other. I want to contrast this practice with that of taking an oath on the name of a sacred text-in which what is put at risk is not the life of one's beloved other but one's own reputation for truthfulness.

\section{Swearing and the Name of the Sacred}

Geoffrey Hughes (1991), the historian of coarse language, has established that a shift occurred in modes of swearing from the $16^{\text {th }}$ century to today, so that the formal and respectful forms of swearing in the English-speaking world have given way to swearing that is close to cursing. Respectful forms of oath-taking, he says, are now seen primarily within formal institutions such as courts of law or at the inauguration to political office. Hughes offers some broad distinctions among modes of swearing. In his words, 'We swear by, we swear that (something is so), we swear to (do something), we swear at (somebody or something), and sometimes we swear simply out of exasperation.' (Hughes 1991:4) He then goes on to declare that the crude history of swearing, however named, is that people used to swear by or to, but now they swear mostly at.

The Indian languages I work with (Hindi, Urdu, Bangla, Gujarati, Punjabi) still have to find their historian of the underworld of language; in my ethnography of the everyday, though, the spheres within which one would swear by or swear that were somewhat different from those in which the primary mode of swearing was that of swearing at. The latter forms of swearing slid into obscene talk and will not concern me here.

Similar to the scenes we see in the Rāmacaritamānasa, people used the devices of 'swearing by' on momentous occasions as well as in the everyday run of things. For instance, gift giving on routine visits among relatives often involved an elaborate

South Asia Multidisciplinary Academic Journal, 12 | 2015 
performance of offers and refusals. A common scene was that of a younger married sister bringing an expensive gift for her brother's children when visiting his household. Since sisters are seen as appropriate recipients of gifts but not as individuals from whom one can accept gifts, there was an inevitable performance of the sister thrusting the gift toward her nephew or niece, her brother or sister-in-law engaging in a veritable theatre of gestures of refusal; the sister then saying at some stage-tvānu meri kasam je nā kïti-lit. I bind you with my oath if you say no (to my gift). The implication is that I have put myself on the stake for this and if you refuse the gift then you have belittled my life. The exchange might end with either a reluctant acceptance, with words such as 'one gives to sisters, one does not receive from them' or a return gift even larger than what was given. Elsewhere, I have examined what I called the aesthetics of kinship in gift-giving (Das 2012). ${ }^{3}$ Here I want to simply point out that verbal forms such as swearing on oneself are much more common when it is a person who is subordinate who is urging an action on the part of a superior. If the person is older or more powerful in kinship hierarchy, then it would be much more common to swear on the name of a younger person. Reversals of this principle are dramatic occasions, as was the case when Rāma swore not only on the name of Lakșmana but also on the name of his lamented father.

Sometimes in serous family disputes or when innocence has to be established, as was the case with Bharata, one might be asked to take an oath on the name of a sacred text. One such case I witnessed was in a Muslim household in which an aunt of a young girl had made an accusation that she had seen the girl with a boy in the market place. Given the strictness of norms of purity and honor that center around the surveillance of the behavior of young women, her parents were extremely angry with her and dragged the aunt to a family assembly in which the family Quran was produced and the girl was asked to swear by the Quran that she had not been out with a boy. The girl was crying but, putting her hand on the Quran, she said 'I swear by the Quran that I never went out with anybody.' Even the aunt, gossip monger though she was, could not bring herself to say that the girl was lying and went away muttering that she might have been mistaken. 'Nobody would dare to swear falsely on the Quran'-this was a common refrain heard after the event, but some older people also said that it was wrong of the parents to have settled the matter with the help of the Quran. One old woman definitely told me that she would not have ever sworn by the Quran even if she were innocent. Recall here Kauśalyä's words that she never swears by the name of Rāma but was making an exception to salvage Bharata's name.

One day in a heated discussion on whether Aurangzeb was a good 'Indian' among a group of friends that included Zargham Mian (a Muslim) and Ranjit Singh (a Sikh), in one of the low-income areas in my field site, the topics ranged from the imposition of the jazia tax ${ }^{4}$ on Hindus to whether Aurangzeb was the first king to have envisaged India as a nation. But then Rantjit Singh produced his own argument with the help of the letter of victory written by Guru Gobind Singh, the tenth guru of the Sikhs, to Aurangzeb after the battle of Chamkaur in 1704, in which he had accused Aurangzeb of being a bad Muslim for having broken an oath he had taken on the Quran.

I believe that Ranjit Singh was referring to the verses in which the guru says that, having promised him safe passage out of Anandgarh fort by swearing on the Quran and then attacking his forces, Aurangzeb had shown himself to have betrayed his religion. ${ }^{5}$

mārā aitbār bar n kasm-e-nīst

ke eizad gavah ast yazdan yakist (Verse 12) 
na katreh mārā aitbār-e bar-ost

ki bakshi va dwan hameh kizb gost (Verse 13) grammatical case. As Keiden (2011) makes clear, the rules on the kārakas, or cases, are premised on a distinction between the semantic content or semantic role of a verbal argument (käraka) and the morphological form (vibhakti the particle that is attached to the word as case ending). It is then interesting to see that the person on whose name one swears is put in the karana käraka or the instrumental case. There is an example in the Kiṣkindhā Kānḍa from Vālmīki's Rāmāyaṇa, in which Rāma comes across the deposed monkey King Sugriva and promises to restore his kingdom and his wife to him by defeating his brother Valī.

tvam hi pānipradānena vayasyo me 'gnisākșikah

kṛtah prāṇair bahumatah satyenāpi śapāmy aham (Kiṣkindhā Kānḍa, Verse 8.26)

For us the interesting part is the phrase 'satyenāpi śapāmy aham'-I swear by truth-for we see that the medium through which one swears is put in the instrumental case. The general rule governing the instrumental case is that what stands in a sentence for the most effective means through which an action is to be accomplished takes the form of the instrumental case and stands in a relation of subordination to the kartā, the grammatical agent of an action, who is defined as svatantra, or unconstrained. I believe that in the grammatical rule that prescribes the instrumental case in relation to the verb shap (oath taking, swearing) we have not only a grammatical rule but a whole philosophy of the person that our discussion of names has opened a door to. 


\section{Taking multiple names}

That the names of gods function as adjectives, condensed descriptions of qualities or events, is a well-known feature of Hinduism and carries important implications for devotional practices (Das 2008). Thus Pārvatī and Umā both refer to the goddess being a daughter of the mountains. One of her names, Aparnāa, signifies that she performed severe austerities, refusing to eat even leaves for nourishment (a-parnā deprived of leaves) when she performed penance to win Śiva's love; her name Umä can also mean 'do not' alluding to Menakā (her mother) asking her daughter to give up the severe austerities she performed in order to get Śiva as her husband. As Satī she is the previous incarnation and the daughter of Dakṣa; as Śivānī she is the one with the Śiva element in her. Devotees will use her one hundred and eight names for meditation while Himalaya is said to have invoked her 1008 names in his prayers, each name referring to a different aspect of her being.

I am tempted to use here Wittgenstein's (1968) idea of aspect dawning when he is discussing the duck-rabbit picture, for it is not as if the duck is the true picture or the rabbit is the true picture but that both are simultaneously present-yet we now see it as a duck and now as a rabbit. It is not that we mechanically oscillate between the two aspects but seeing now the duck and now the rabbit are both potentials contained in the picture. Applying this important insight from Wittgenstein to the case of the multiple names of gods and goddesses, I suggest that each name condenses the different possibilities inherent in any narrative rendering, regardless of which one is realized at any one time. There are, however, limits to this analogy since aspect dawning is strongly tied to visionwhat it is to see something as something-now a rabbit, now a duck. In the case of the multiplicity of names that might come to stick to a person, we might have a different set of questions occasioned by the fact that names are primarily words not pictures (though a picture might be conjured by a name). We may ask: does naming work by fixation or by movement and metamorphosis? In the concluding comment I will return to this question from a comparative perspective. For now let us take the example of Draupadi from the Mahābhārata to illustrate how her different names come to condense the different layers of the narrative signaling the important idea that a narrative might reveal itself to be simultaneously enacted on different planes, in different spaces and in different times.

Recall that Draupadi is the princess who was staked in a game of dice by Yudhisthira, the eldest brother of the five Panndavas-the protagonists of the epic who were denied their rightful share in the kingdom by their half-brothers, the Kauravas. This injustice led to a war between the two related patrilineages-but this war of total destruction also marked the move of mankind into history-or the period of kaliyuga. The difference between the two epics-the Rāmāyana and the Mahābhärata-we are considering here is described by Sheldon Pollock in these terms:

The works are, in a fundamental way, complementary. [...] Both poems relate a struggle over succession to the throne, leading to a degradation of the princess and the political power she represents and (before or after that) the exile of the protagonists, war, return, and recovery of the throne. But here too the complementarities are telling. Most important is the agon itself; the Rāmāyana is a tale of 'othering,' the enemy is non-human, even demonic, and the war takes place in an unfamiliar, far-away world; the Mahābhārata is a tale of 'brothering'; the 
enemy are kinsmen-indeed, as the protagonists say, almost their own selves-and the war takes place at home. (Pollock 2007: 34) Yagyasenī, and Krishnā-that occur in different places in the text. ${ }^{6}$ Draupadi the name used most frequently for her simply means, the daughter of Drupad-just as Jānaki in the Rāmāyana is simply daughter of Janak. In the course of the story of the humiliation of Draupadi in the court of Kurus, the subsequent war and the avenging of her insult, we also learn that within the mythic logic of the text, Draupadi (whose other names Pānchali and Yagyaseni point to her dark origin) is but the instrument of the will of gods born to ensure the complete destruction of the Kurus and the Pānchālas, the two powerful Kșatriya lineages, whose incessant warfare has made the earth tired. Her name, Pānchālì, signifies her birth in the kingdom of the Pānchāla and along with Yagyasenī refers to another story within this rich tapestry of stories. The essential elements of the story are as follows. Drona, a Brahmin and Drupada, a Kșatriya and the future Pānchāla king, are childhood friends. However, a terrible enmity develops between them and Drupada is humiliated in battle by Drona. Burning with the fire of vengeance, he performs a firesacrifice with the help of two priests to ritually produce a son for him who will kill Drona and avenge his defeat. A mighty son is born from the sacrificial fire, but unintended by the sacrificers and initially unnoticed by anyone, a beautiful girl is also born from the sacrificial altar. Hence her name Yajyasenī.

What is the meaning of this birth, a residue of the sacrifice-a clear acknowledgement that the human king might have had one kind of purpose (wreaking vengeance on his enemy) in performing the fire sacrifice, but the gods have used that very moment for setting into motion a different kind of violence? The text tells us that as soon as she was born, a disembodied, heavenly voice announced that Krishna (another name for Draupadi referring to her dark associations and her affinity with Kali, the goddess of death and time) will accomplish the work of gods and lead the Kstriyas to their destruction. Indeed, the prediction comes true in the course of the great battle. Thus the names are pregnant with the future possibilities of the narrative and are an important means for the sideshadowing that Hiltebeitel (2001) sees as an essential element of storytelling in Hindu texts.

As Saria's essay on name changing among the hijras (in this volume) argues, there is a subjunctive element in the hijra practices of name changing-a desire to cut themselves off from a past or from relationships that have been corroded. In the case of multiple names of characters in the epics, there are two implicit theoretical claims on what names can mean. First that our fully-realized selves are embodied in the most well-known and public name one is known by (e.g. Draupadī); second, that name hides in it other possibilities of who we could become. Unknown to herself, Draupadī is also an instrument of the gods who leads the two lineages to their destruction just as in swearing by the name of another one ends up making him or her into an instrument for one's own projects-a feature condensed in the grammatical rule on the karana käraka-the instrumental case-discussed earlier. I find it poignant that during their exile in the forest when the Pāndavas were enjoined to remain completely anonymous for one year, Draupadi took the name of Sairandharī-female servant. In the end was she but an instrument of the will of the gods, a servant to accomplish what the others, standing outside the social, wanted of her? 
40 Investigations, when Wittgenstein (1968) alludes to the various descriptions that can attach to a name. It is worth citing this paragraph at some length:

Consider this example. If one says 'Moses did not exist,' this may mean various things. It may mean: the Israelites did not have a single leader when they withdrew from Egypt-or: their leader was not called Moses-or: there cannot have been anyone who accomplished all that the Bible relates of Moses-or: etc. etc. We may say, following Russell: the name 'Moses' can be defined by means of various descriptions. For example, as 'the man who led the Israelites through the wilderness,' 'the man who lived at that time and place and was then called "Moses", 'the man who as a child was taken out of the Nile by Pharaoh's daughter' and so on. And according as we assume one definition or another, the proposition 'Moses did not exist' acquires a different sense, and so does every other proposition about Moses [...]

But when I make a statement about Moses,-am I always ready to substitute some one of these descriptions for 'Moses'? [...] Has the name 'Moses' got a fixed and unequivocal use for me in all possible cases?-Is it not the case that I have, so to speak, a whole series of props in readiness, and am ready to lean on one if another should be taken from under me and vice versa?

Wittgenstein goes on to observe that a name does not have a fixed meaning, but that does not distract from its usefulness any more than the usefulness of the term 'table' when it comes to refer to an object next to my chair that has three legs instead of four, and therefore sometimes wobbles. ${ }^{7}$ In other words, the suggestion here is that the relation between the name and the entity it refers to might vary in the context of different descriptions that we might be able to offer of that person. In Saul Kripke's $(1971,1980)$ well-known formulation on rigid designators, proper names are rigid designators because names of the same objects remain true in all possible worlds. In one of his examples-say, if Hitler had never been born, Hitler would still refer-and rigidly-to something that would not exist in that possible world. But at this point it seems interesting to ask what makes it intuitively correct for us to imagine that if someone says 'If Hitler had never been born, the world would have been a better place,' we know that this entity that does not exist in that counterfactual world is Hitler. However, if someone says 'I don't believe that anyone called Moses existed because no one could have performed all those things that Moses is said to have done,' it is possible to imagine that Moses does not refer to any particular entity in any rigid sense. What makes the difference between the fixity of one and the relatively open texture of the latter is not anything derived from logic but from our sensibilities regarding what is history, what we express when we say if only Hitler had never been born, and our astonishment, if we do not have much use for miracles, that anyone could imagine that a person by the name of Moses could have made the sea to part. The open texture of a name may be brutally curtailed when one comes under the eyes of the State, as in applying for a passport-in other contexts such as the names lovers might give to each other, the question shifts to asking what different kinds of histories of a relationship are condensed in the names that are in movement or in transformation from one to another?

The multiplicity of names that I discussed in the case of Draupadi was anchored to the multiple possibilities of a narrative and the fact that any one event always contained shadows of other lives the same character might have lived (Hiltebeitel 2001). Who it is who knows who you are might be recast in terms of questions about which names stick, when do they become rigid, and who has the right to use what name for you? These

South Asia Multidisciplinary Academic Journal, 12 | 2015 
questions eventually lead one to the issue that the multiplicity of names, or multiple descriptions of a name, raise-viz., whether one is the same person for different people and whether there is essentially any one person that you are.

\section{Name, foreshadowing of death, and ghostly lives}

43 In the introductory paragraphs of this paper I referred to two important aspects of naming that I took from Lévi-Strauss's discussion of Penan names. The first was the poles of stability and immutability on the one side and changeability and mutability on the other within which names move. The second was the relation names bear to death. In the Penan case the necronym refers to a kinship tie that has come to an end. As Lévi-Strauss states the issue:

The necronym contains no proper names at all and consists in the statement of kinship relation, which is that of an unnamed 'other's' relation with a self equally unnamed. It can therefore be defined as an 'other' relation. And finally, this relation is negative since the necronym mentions it only to declare it extinct. (LéviStrauss 1966: 192)

Might we find shadows of the necronym-not necessarily in the form that naming takes in the Penan case but in other ways in which the relation between a name or the manner of our using it, might attune us to declarations of how death is encoded in the relation we bear to names.

I met a woman in 2012 in a village on the fringes of Delhi, in the course of a focus-group discussion on reproductive health and institutional births that I was participating in. Although she did not bring up her experiences in the focus group discussion, later, when we were having tea, she told me as an aside that she did not have any children. Then in a curious juxtaposition she said-'main gharwale ko Munne ke bapu, Chotti ke bapu-aise keh ke to bula nahin sakti na-name leti hun.' Literally translated her statement says in effect that since they have no children she cannot use the usual forms of address for her husbandsuch as 'Munna's father' or 'Chotti's father' and hence used (lit. took) his name, Suresh. At first I could not understand the import of the story-and why the whispered confidence about being childless was immediately followed by the revelation of her 'taking' the name of her husband. I know the taboo in India that prohibits a wife from uttering the husband's name and the fear that such an utterance shortens the life of the man. Responding to my somewhat bewildered look, she explained further. It seems she had lost all her six babies either during birth or right after. In four cases she had miscarried in the advanced stage of pregnancy and in two cases they died within a few hours of being born. The bitterness in her voice was evident-'My husband, could make me pregnant again and again but he could not be bothered to take me to a proper doctor or to a proper hospital. His drinking was more important to him then the lives of my children. Even now his relatives taunt me-calling me banjh (a pejorative term for a woman who is infertile)-so I too wish him a bit of death everyday by taking his name.' By the phrase 'taking his name,' she did not mean that she called him by his name (that might have been socially unacceptable) but that if she had to send a message to him through another person when he was in the street or drinking with his friends, she would say to a neighbor or to a boy who was going in that direction-'go, tell Suresh.' In this way, she uttered his name many times in the day and each time brought a little bit of death on him. Her revenge on the 
stigmatized name of banjh, with which her conjugal relatives slighted her existence as a childless woman was to wish another stigma on herself-that of becoming a widow.

The second case that I offer for discussion is the opposite of the first one, in which a woman could not bear to take the name of her abuser. I have discussed this case in an earlier paper (Das 2014) but juxtaposing this case with the previous one makes the dynamic relation between a name and the foreshadowing of death more complex. It also helps to show how the idea of a necronym takes us to a very important region of everyday life that might not be evident in the formal system of naming, but dawns on us in the way people use names or withhold themselves from uttering particular names. While one might be accorded a place in the social scheme of things through the public name one carries, whether one recognizes oneself in it is more than a simple matter of following rules-behind the rules lie whole histories of relationships that give everyday life its particular texture.

Sheela's family is among the small number of upper-caste families in Punjabi Basti, a lowincome neighborhood in West Delhi. Her natal family had escaped from the riots in Pakistan, but her father died soon after. So she grew up in her maternal uncle's house along with her mother, two sisters, and five older cousins. She was married at an early age to a much older man, who in other circumstances would have been considered below the status of her natal family. And although she never narrated in one long story the facts of her sexual abuse as a child, little bits of her story would come out on different occasions when we were together, in such expressions as 'Mere naal vi bure karam hoye' (bad acts happened with me too). ${ }^{8}$ For instance, once when she was helping her eightyear-old granddaughter to change into a new dress, she became tearful and, putting her hand on her mouth as if to block speech from bursting out, said, 'Oh god, this is how little I was when...' She did not elaborate, but something in her past had rotated and confronted her at this moment. ${ }^{9}$ As a child Sheela was often slapped, sometimes figuratively if not actually beaten with sticks [dande padte the], not by her other relatives but by her mother. This aspect, though, she recalled with a kind of cheerfulness, commenting that her mother had to beat her to signal her own status toward her relatives, who, though not well off, had taken the additional burden of dependent relatives. 'What could she do-there was a compulsion [mazboori thi].' Elsewhere I have described this as the aesthetics of kinship (Das 2012).

Though she let some expressions of her hurt escape in my presence, I never asked and she never said whether she had told the story of her abuse to anyone, including her husband. As I have described elsewhere, in matters of sexual violation, there is an agreement in families displaced by the Partition that one does not ask any explicit questions; instead one allows oneself to be marked by the knowledge that comes one's way. Here the anthropologist's mode of being converges into that of the others in the community. There were two occasions, though, when Sheela did tell me something. The first occurred when I told her that there was a discipline called psychoanalysis in which therapeutic interventions consisted of the 'patient' talking every week for an hour with the therapist, saying whatever came to her mind. She said that she wished she could find a guru who would understand her without her having to say anything. Then she went on to say that she could imagine 'talking' about those things, but she could not imagine ever saying aloud the name of the person who had violated her. 'I cannot even say it aloud to myself. It is like I am holding something in me, tight as a fist, a coiled snake, and if that came out, the world would be thrown into chaos [duniya utthal putthal ho jayegi].' 

inability to name her abuser relate to the first case of Suresh's wife insisting on uttering his name when she could? We know that uttering some names repeatedly such as the name of a beloved god or goddess in devotional practice brings merit. In other cases married women say that the refusal to speak the name of one's husband comes from the desire to protect and honor him and its violation as we saw in the first case, is nothing short of wishing death upon one's husband. In Sheela's case, however, her abuser did not stand in any normative relation to her, yet she said she feels nauseous, physically ill and in the throes of a panic if she were to pronounce her abuser's name even silently to herself.

There is another register of proper names that might have a resonance with the dread that Sheela feels in uttering the name of her abuser. While it is meritorious to recite the name of any god or goddess, as I said, it is only the ritual adepts, such as diviners, who can safely get a demon to reveal its name. Does Sheela, then, place her unnamed abuser in the position of a demon-would the utterance of his name conjure him up? This explanation too falls short of capturing the kind of intensity with which Sheela described her dread of this utterance. Sheela, after all, is not talking about someone else, a third person, whether human or demon, but about herself, the first person-and one's relation to oneself is not based on observational knowledge. As Anscombe (1981) argued in her classic essay on the first person, one does not use the word I to refer to oneself as one would use other pronouns to refer to a second or third person. Although there might be room for debate on Anscombe's claim that the pronoun 'I' is non-referential under all conditions, there is, indeed, little doubt whom I mean when I use the first person. The self is not one object among others; I do not infer how I am feeling by observing myself. Yet in Sheela's experience, there is a name embedded in her body that destroys the intimacy she has with herself. She cannot let go of this name without making the universe go topsyturvy. She cannot bear to make that part of herself known in which this name resides as a hostile alien.

\section{A concluding comment}

51 I argued that juxtaposing some compelling ethnographic moments with literary examples, helps us to think of the varied facets through which names course through life. As in the other essays in this volume I have tried to show how the South Asian material on names and naming can be brought to bear on theoretical issues around the play between singularity and multiplicity, contingency and necessity and the person as both autonomous and an instrument of the will of the other. Perhaps the most important lesson I learnt from engagement with texts and lives is that the name can provide a window into the way in which everyday life is imbued with the dark hues of violence, betrayal, and the corrosion of relationships. And yet, names also hold the promise that we can bet on the trust we place in others as one important way to redeem everyday life, as the examples from the trust Rāma placed in Bharata show. 


\section{BIBLIOGRAPHY}

Anscombe, Elizabeth A. (1981) 'The First Person', in Metaphysics and the Philosophy of Mind: Collected Philosophical Papers Volume II, Oxford: Basil Blackwell, pp. 21-37.

Augé, Marc (2011) La Vie en Double: Ethnologies, Voyages, Ecriture Paris: Payot et Rivages.

Bhava-bhūti, Rama's Last Act, translated by Sheldon Pollock, New York: Clay Sanskrit Library.

Crapanzano, Vincent (2003) Imaginative Horizons: An Essay in Literary-Philosophical Anthropology, Chicago: The University of Chicago Press.

Das, Veena (1982) 'Kāma in the Scheme of Puruṣarthas: The Story of Rāma', in T.N. Madan (ed.), Way of Life: King, Householder, Renouncer: Essays in Honour of Louis Dumont, Delhi: Motilal Banarasidas Publications, pp. 183-204.

Das, Veena (2007) Life and Words: Violence and the Descent into the Ordinary, Berkeley: University of California Press.

Das, Veena (2008) 'If This Be Magic ... Excursions into Contemporary Hindu Lives', in Hent de Vries (ed.), Religion Beyond a Concept, New York: Fordham University Press, pp. 259-82.

Das, Veena (2012) 'Ordinary Ethics', in Didier Fassin (ed.), A Companion to Moral Anthropology, Malden (Massachusetts): Wiley-Blackwell, pp. 279-306.

Das, Veena (2014) 'Action, Expression, and Everyday Life: Recounting Household Events', in Veena Das, Michael Jackson, Arthur Kleinman \& Bhrigupati Singh (eds.), The Ground Between: Anthropologists Engage Philosophy, Durham: Duke University Press, pp. 279-306.

Das, Veena (2015) 'Fleeting Moments that Last Forever: Violence to and Against the Everyday', Paper presented to Mahendra Humanities Center, Harvard University, Cambridge (Massachusetts): October 26.

French, Louis (2013) The Sikh Zafarnamah of Guru Gobind Singh: A Discursive Blade in the Heart of the Mughal Empire, New York: Oxford University Press.

Hiltebeitel, Alf (2001) Rethinking the Mahābhārata: A Reader's Guide to the Education of the Dharma King, Chicago: Chicago University Press.

Hugh, Geoffrey (1991) Swearing: A Social History of Foul Language, Oaths and Profanity in English, Oxford: Blackwell.

Jackson, Michael (2013) The Other Shore: Essays on Writers and Writing, Berkeley: California University Press.

Karve, Irawati (2008 [1968]) Yuganta: The End of an Epoch, Delhi: Orient Black Swan.

Keiden, Artemig (2011) 'The Kāraka-Vibhakti Devise as a Heuristic Tool for a Compositional History of Pāṇini’s Așțādhyāyī,' Studi Orientali: Nuova Serie, Vol. LXXXIV (1-4): 273-88.

Kripke, Saul (1971) 'Identity and Necessity', in Milton Karl Munitz (ed.), Identity and 'Individuation', New York: New York University Press, pp. 135-64.

Kripke, Saul (1980) Naming and Necessity, Cambridge (Massachusetts): Harvard University Press.

Lévi-Strauss, Claude (1966) The Savage Mind, Oxford: Oxford University Press. 
Lutgendorf, Phillip (1991) The Life of a Text: Performing the Ramcaritamanas of Tulsidas, Berkeley: University of California Press.

Needham, Rodney (1954) 'The System of Tekonyms and Death Names of the Penan', Southwestern Journal of Anthropology, 10(4), pp. 416-31.

Pandey, R. (1976) Rāmacaritamānas kā śāstrīya adhyayan (A scholarly study of Rāmacaritmānas), Kanpur: Pustak Sansthan.

Parry, Jonathan P. (1986) 'The Gift, the Indian Gift and the 'Indian Gift” Man, 21(3), pp. 453-73.

Pollock, Sheldon (2007) 'Introduction', in Rama's Last Act, New York: Clay Sanskrit Library, pp. 2762.

Raheja, Gloria G. (1988) The Poison in the Gift: Ritual, Prestation, and the Dominant Caste in a North Indian Village, Chicago: The University of Chicago Press.

Richman, Paula (1991) 'Introduction: The Diversity of Ramayana Traditions', in Paula Richman (ed.) The Diversity of a Narrative Tradition in South Asia, Berkeley: University of California Press, pp. 3-21.

Singh, Guru Gobind (1967 [1707]) Zafarnama, translated by Dharmendra Nath in Hindi as Vijaypatrika, Delhi: Akhil Bharatiya Vidyapeeth Prakashan.

Stasik, Danuta (2009) 'Perso-Arabic lexis in the Rāmcaritmānas of Tulsīdās', Cracow Indological Studies, Vol. XI, pp. 1-20.

Wittgenstein, Ludwig. (1968) Philosophical Investigations, translated by G.E.M. Anscombe, London: Macmillan Press.

\section{NOTES}

1. I thank the three anonymous reviewers of SAMAJ for their meticulous reading of an earlier draft and critical comments that helped enormously in improving the argument. I am also very grateful to those who commented on the paper when it was first presented at Madison in 2014 and to my fellow contributors, especially Jacob Copeman, for an exciting adventure with names.

2. Rāmacaritmānas is the magnum opus of the poet Tulsidas and was composed in 1574. It is regarded as a new telling of the inexhaustible Rāmakathā-the sacred story of Rāma. Tulsidas himself calls the language of the composition-bhāshā-lit. language, i.e. a broad term for vernacular languages. Although some authors characterized the language of the Rāmacaritmānas as Baisavari, there is a general consensus that its language is Avadhi of which Baisavari is a dialect. The text has a number of full phrases and words adapted from different languages including Persian loan words (see Pandey 1976 and Stasik 2009)

3. Although there is an impressive literature on the relation between gifts and caste or affinal status (Parry 1986; Raheja 1988), what I want to emphasize is the style of giving and refusing gifts.

4. The reference is to the following verse in the Quran: 'Fight those who do not believe in Allah, nor in the latter day, nor do they prohibit what Allah and His Apostle have prohibited, nor follow the religion of truth, out of those who have been given the Book, until they pay the tax in acknowledgment of superiority and they are in a state of subjection' [Quran 9:29].

5. This is the only text Guru Gobind Singh wrote in Persian. I have used phonetic spellings for the Persian verses. Several translations in Hindi and Punjabi are available (see Sing 1967); and for an interesting discussion on discursive contests and claiming of spiritual authority, see French (2013). 
6. The various names of Draupadī might be grouped as tekonyms-Draupadī, Drupadkanyā, etc. referring to her lineage; others are adjectival referring to several features such as her beautiful smile-Mālinī, or her youth-Nitayuvanī. The names Krishnā-the dark one and Yajyasenī-born of the sacrificial fire-have special importance because they point to the different layers in the story.

7. Marcos Motta informs me that in Zanzibar the spirit who manifests itself in ritual might treat the human body as the table!

8. I have used phonetic spellings for spoken Punjabi and Hindi.

9. See Das (2007) for the notion of rotation in Bergson's discussion of time and how it allows a certain region of the past to become present in the telling of a story.

\section{ABSTRACTS}

This paper argues for a theory of naming beyond the philosophical concerns with proper names as the test case for theories of reference. Moving forward from anthropological concerns of naming practices as forms of convention, I argue that names in the Indian tradition participate in a wider problematic in which the name opens the person to the world as it also makes her vulnerable to the world. Taking examples from my long time ethnographic engagement with families in Delhi and juxtaposing these examples with iconic moments of naming in stories from two Indian epics, the Rāmāyana and the Mahābhārata (including their vernacular versions) the paper shows that attention to how names are used alerts us to such existential questions as whether one remains the same person to oneself and to another over the course of a life time.

INDEX

Keywords: names, immutability, volatility, death, epics

\section{AUTHOR}

\section{VEENA DAS}

Department of Anthropology, John Hopkins University, Baltimore 